\title{
Analysis on Needs Based Survey of Parents and Speech-Language Pathologists for Smartphone Programs
}

\author{
Dongsun Yim, Shin-Young Kim, Wonjeong Park, Seonghye Cheon, Yeo-Jin Lee \\ Department of Communication Disorders, Ewha Womans University, Seoul, Korea
}

Correspondence: Dongsun Yim, $\mathrm{PhD}$ Department of Communication Disorders, Ewha Womans University, 52 Ewhayeodae-gil, Seodaemun-gu, Seoul 120-750, Korea Tel: $+82-2-3277-2120$

Fax: +82-2-3277-2122

E-mail: sunyim@ewha.ac.kr

Received: October 2, 2014

Revised: November 7, 2014

Accepted: December 1, 2014

This work was supported by the National Research Foundation of Korea grant funded by the Korean government (Ministry of Science, ICT \& Future Planning) (NRF-2013R1A2A2A03068010).
Objectives: The aim of this study is to examine the needs of parents and speech language pathologists (SLPs) when developing mobile-based contents as intervention tools for children with communication disorders. Methods: Questionnaires were developed through preceding research; assessment tools and reference data from Statistic Korea were verified by two professionals for validity and suitability. The survey was conducted in person, by mail, or online format. A total of 189 of questionnaires were chosen for analysis ( 96 families of children with communication disorders and 93 SLPs). Results: More than half of the 189 subjects responded that they have used smartphone applications to improve the communication skills of a child. Educational content for parents is highly desired by both parents and SLPs, while the parent group needed more quantitative information about proper utterances for themselves as conversation partners. And while parents highly desired educational material, most interactions between them and their SLPS were consultation-based. Conclusion: The results of this study suggest that a follow-up study is needed to provide communication care service via smartphone applications for speech-language intervention.

Keywords: Children with communication disorders, Speech-language pathologists (SLP), Parents, Smartphone, Survey, Needs investigation
현대 사회는 스마트 미디어 사회(Smart Media Society)로 정의할 수 있다(Croteau, Hoynes, \& Milan, 2012). 미디어란 정보가 전달되 는 통로이자 매개체로(Buckingham, 2013), 특히 스마트 미디어는 시간적·공간적 제약 없이 융합 콘텐츠를 제공하며(Kim \& Kim, 2012) 양방향적 소통이 가능한 사용자 참여형 또는 맞춤형 전달 매 체로 정의할 수 있다(Cho, 2011). 스마트 미디어의 대표적인 예로 네 트워크 컴퓨터, 스마트폰, 태블릿 PC 등을 들 수 있으며, 특히 2013 년 정보통신정책연구원(Korea Information Society Development Institute)의 보고에 따르면 한국 사회에서는 스마트폰이 일반 휴대 전화의 보급률을 뛰어넘은 것으로 나타나 보편적인 휴대용 통신기 기로 통용되고 있다고 할 수 있다. 실례로 2013년 7월 구글코리아에 서 전국 18-64세 성인 남녀 1,000명을 대상으로 실시한 '한국 모바 일 소비자의 이해' 조사 결과, 한국 소비자의 스마트폰 보급률은 $73 \%$ 로 2011년 1분기에 발표되었던 27\%에 비해 세 배 가까이 증가한 것
으로 나타났다. 이는 구글의 조사 대상이었던 43 개국 가운데 가장 높은 성장률이며, $82 \%$ 의 사용자가 매일 스마트폰을 사용하는 것 으로 밝혀져 스마트폰 사용량 또한 아시아-태평양 지역에서 가장 높은 수치를 보였다. 또한 스마트폰에 설치한 어플리케이션 수도 평 균 40.1개로 조사 대상 국가 중 1위를 차지했다. 이렇듯 스마트폰은 한국 사회에서 일상생활 깊숙이 자리 잡고 있다.

한편 청각장애, 지체장애, 자폐성장애 등 여러 가지 원인으로 인 하여 말·언어장애가 나타날 수 있으며, 유창성 장애나 조음장애, 단순언어장애 등 말 및 언어에 특정적인 장애가 나타나는 경우도 있다. 일반적으로 의사소통 영역에 있어서 중추신경의 문제로 인하 여 유발되는 장애를 언어장애(language disorders)로, 호흡기관 또 는 발성기관, 공명기관 등 주변 기관의 손상으로 인하여 발생하는 장애를 말장애(speech disorders)로 분류해 왔으나, 말장애와 언어 장애는 동시에 나타나기도 하며 두 가지 모두 결국 타인과의 의사 
소통에 어려움을 가져오는 바, 최근에는 의사소통장애(communication disorders)로 통칭하는 추세이다(Sim et al., 2011). 즉, 의사소 통장애는 여러 가지 원인으로 타인과의 상호작용에 어려움을 초래 하는 것을 뜻하는 포괄적인 개념을 갖는다고 볼 수 있으며, 본 연구 에서도 의사소통장애에 대하여 이러한 정의를 사용하고자 한다. 정보기술의 비약적인 발전을 특징으로 하는 스마트미디어 사회에 서는 이러한 의사소통장애를 다루는 방식 또한 새로워졌는데, 컴 퓨터 기술을 활용하여 의사소통능력을 증진시키고자 하는 다양 한 하드웨어·소프트웨어적 접근이 이루어지고 있다(Lim \& Park, 2012). 컴퓨터를 이용한 교수방법인 Computer Assisted Instruction (CAI, 컴퓨터 보조학습)(Heimann, Nelson, Tjus, \& Gillberg, 1995; Hwang et al., 2014), 로봇을 활용한 자폐 아동 중재(Goldsmith \& LeBlanc, 2004), PC 및 스마트 기기를 활용한 Argumentative and Alternative Communication (AAC, 보완대체의사소통)(Cafiero \& Meyer, 2008; McNaughton \& Light, 2013) 등은 의사소통장애 아 동의 의사소통 기능 및 상호작용 기능을 높이는 데 기여하고 있다. 더불어 의사소통장애 아동의 중재에 양방향 소통형의 스마트 미디 어를 활용하는 접근은 임상에서 점진적으로 증가하는 추세이며 (Ha \& Kang, 2011), 스마트폰 시장의 확대와 관련 기술의 발달이 이 러한 흐름에 중요한 역할을 하고 있다.

다른 스마트 미디어에 비해 더욱 광범위하게 보급된 스마트폰을 다양한 분야에 활용, 실생활에 접목하여 인간의 생활을 더욱 윤택 하게 할 수 있는 가능성에 주목한 연구가 최근에 있어 왔는데, 스마 트폰을 재활 및 치료에 응용한 사례로는, 미국에서 알코올 중독(alcoholism) 환자를 대상으로 스마트폰을 통해 A-CHESS라는 프로 그램을 제공한 후 그 효과를 검토한 연구가 있다(McTavish \& Gustafson, 2012). 349명의 알코올 중독 환자들에게 A-CHESS 프로그 램이 장착된 스마트폰을 제공하여 재활에 관한 다양한 정보 및 피 드백을 제공하였으며, 환자의 $70 \%$ 이상이 꾸준히 이 시스템을 이 용하여 보다 능동적으로 본인의 문제에 접근할 수 있었다고 보고 하였다. 또 다른 사례로는 당뇨병 환자 15명을 대상으로 스마트폰 에 공복 혈당과 식습관, 신체 활동 및 감정에 대해 일기를 작성하도 록 하고, 전문가가 실시간으로 이에 접근하여 피드백을 제공하여 그 효과를 살펴본 연구가 있다(Nes et al., 2012). 참가자들은 생활 습관이 긍정적으로 변화하였다고 보고하였으며, 한 명을 제외한 모든 참가자가 전문가의 피드백이 도움이 되었다고 대답하였다.

언어병리학 분야에서도 다양한 매체를 활용하여 아동의 언어발 달을 촉진하기 위한 노력이 계속되고 있는데, 아동의 음성을 영상화 하여 언어장애 및 자폐범주성장애 아동의 언어치료를 지원(Hailpern, Karahalios, Halle, DeThorne, \& Coletto, 2008)하고, 발화의 속
도를 게임을 통하여 조절(Hoque, Lane, El Kaliouby, Goodwin, \& Picard, 2009)하는 등 데스크톱 컴퓨터를 이용한 언어치료 연구 및 기술 개발 사례를 다수 찾아볼 수 있다. 그러나 이러한 연구들은주 로 데스크톱 환경, 즉 정적인 환경에서의 사용을 위한 기술들이며, 일상생활 속에서 제공되는 생활 밀착형 서비스에 대한 연구를 찾 아보기 어렵다. 이러한 가운데 언어발달 지연 및 장애에 대한 조기 진단과 평가를 목적으로 한 LENA Foundation의 아동 언어환경 분석 프로그램(language environment analysis, LENA)에 주목할 만하다. 이는 아동의 언어환경을 분석하고 아동의 언어를 일상적 환경에서 손쉽게 수집할 수 있는 기기와 분석 프로그램을 개발하 여 이를 임상에 적용한 사례로서, LENA를 사용하여 아동의 언어 환경에 영향을 미치는 다양한 요인을 살펴본 결과, 부모와의 대화 상황(Zimmerman et al., 2009), 부모의 언어제공(Caskey, Stephens, Tucker, \& Vohr, 2011) 등이 아동의 발화량 및 언어발달과 유의한 상관관계를 보이는 것으로 나타났다. 또한 LENA를 사용한 연구에 서 청각장애(Caskey \& Vohr, 2013), 자폐범주성장애(Warren, Stone, \& Humberd, 2009) 등의 선별도구가 될 수 있음이 나타났고, 부모 가 아닌 보조 양육자를 대상으로 한 연구에서도 기기의 피드백이 아동에 대한 언어적 태도에 유의한 긍정적 변화를 가져왔음을 밝 혔다(Suskind et al., 2013). 그러나 이 기기와 프로그램은 고비용 문 제로 인하여 주로 연구용으로 사용되고 있으며, 임상 및 일상에서 의 보편적인 사용에 어려움이 따르고 있다. 만약 스마트폰 어플리 케이션을 통하여 보다 저렴한 가격으로 아동의 언어 환경에 대한 정보를 제공할 수 있다면, 의사소통장애 아동의 조기 선별의 도구 로 유용하게 사용될 수 있을 것으로 기대된다.

의사소통장애 아동에 대한 치료에서 부모 역할의 중요성은 많은 선행연구들에서 밝혀진 바 있다(Hemmeter \& Kaiser, 1994; Lee \& Seok, 2006; Pennington, Thomson, James, Martin, \& McNally, 2009; Roberts \& Kaiser, 2012). 부모를 치료에 직접 참여(Crais, Roy, \& Free, 2006; Hanna \& Rodger, 2002; Rosenbaum, King, Law, King, \& Evans, 1998) 시키거나 또는 부모 교육을 통한 간접 치료(Gillet \& LeBlanc, 2007; Hemmeter \& Kaiser, 1994; Kaiser \& Roberts, 2013) 의 방법도 그 효과가 많은 연구들에서 증명되어 실제 임상에서도 권장되고 사용되고 있으나, 여러 가지 이유로 부모 교육을 현실화 하기 어려워 치료실 내에서의 부모교육이 가정으로까지 연계되지 않고 있다(Romski et al., 2011). 한편 부모의 사회경제적 지위는 가 족의 부모 교육의 현실성 여부에 영향을 미칠 것으로 예상되는데, 다양한 집단을 대상으로 한 연구에서 부모교육의 선호도 및 효과 는 부모의 사회경제적 지위와 무관한 것으로 나타났으며(Leijten, Raaijmakers, de Castro, \& Matthys, 2013; Rogers, Forehand, Gri- 
est, Wells, \& McMahon, 1981; Wood \& Baker, 1999), 다만 사회경 제적 지위가 낮은 경우 치료 효과의 유지가 사회경제적 지위가 높 은 집단에 비해 낮은 것으로 나타났다(Leijten et al., 2013).

취학 전 영·유아의 경우 부모를 통해 최초의 언어 학습이 이루어 지기 때문에 간접 치료 방식인 부모교육의 중요성이 더욱 강조되는 데(Reese, Sparks, \& Leyva, 2010), 1;0-5;10세의 아동 대상 부모교육 프로그램에 대한 메타연구(Jung \& Yim, 2011)에 의하면, 1980년부 터 2011년까지 이루어진 20개의 연구 가운데 부모교육 프로그램의 유형으로는 Hanen 프로그램을 가장 많이 사용하였으며, 그 다음 으로 부모중심중재(parent-based intervention), 중심자극중재(focused stimulation intervention)가 뒤를 이었다. 또한 메타분석 결 과 부모교육 프로그램이 아동의 언어능력 및 의사소통능력, 그리 고 부모의 상호작용 능력에 유의한 긍정적 효과를 가져온 것으로 나타났다. 따라서 의사소통장애 아동 부모교육이 아동의 언어발 달에 긍정적인 영향을 미친다는 선행연구들을 다시 지지하는 연구 결과라 할 수 있으며, 부모교육 및 언어중재에 있어서 부모의 참여 에 대한 중요성을 확인한 것에 연구의 의의가 있다고 할 수 있을 것 이다. 한편 이 연구에서는 부모교육이 일상생활에서 적용되고 있 는지를 꾸준히 확인하고 모니터링하는 과정이 필요함을 제안하였 는데, 여기에서 스마트폰의 가능성을 검토해볼 수 있다. 선행연구 에 의하면 부모교육을 스마트 미디어를 통하여 제공했을 때 부모 기술이 향상되고 아동의 문제 행동들이 줄어드는 등의 긍정적인 효과가 나타났으며(McGrath et al., 2013), 특히 저소득층 부모들에 게 유용했다(Breitenstein \& Gross, 2013). 따라서 한국 사회에서 일 상생활에 깊숙이 침투한 모바일 기기인 스마트폰을 언어치료 특히 부모교육에 접목할 수 있다면, 접근성의 측면에서 최적의 조건을 갖춘 도구로서 활용할 수 있을 것이다.

스마트폰이 가진 활용성과 가능성을 언어치료에 적극적으로 활 용하여 일상생활에서의 부모교육 및 의사소통장애 아동 선별 도 구로 사용할 수 있다면, 별도의 비용 없이 '일상생활 통합형 의사소 통 지원 서비스(Life-immersive Communication Care Service)'가 가능해질 것이다. 이를 위해서는 우선적으로 실수요자라 할 수 있 는 의사소통장애 아동의 부모 및 언어치료 전문가의 실제적 요구 사항에 대한 검토가 필요하다. 언어병리학 분야에서도 언어재활 서 비스를 제공하는 대상자의 요구 및 현황을 파악하여 중재의 방향 을 설정하고, 수요자 중심 중재를 제공하고자 하는 연구들이 있어 왔다. 이는 주로 설문조사의 형식으로 이루어지는데, 성인 대상자 의 경우 직접 설문조사를 실시하여 특정 중재법의 요구도에 대해 조사하기도 하며(Sutherland et al., 2014), 아동의 경우에는 간접치 료의 대상이 되는 부모를 대상으로 설문조사를 실시하여 아동의
주위 환경을 살펴보기도 한다(Minchom, Shepherd, White, Hill, \& Lund, 2003). 설문조사 연구방법은 수요자가 필요로 하는 요구와 현재의 문제점을 파악하여 이를 충족시킬 수 있는 방안을 검토하 고 앞으로의 방향을 모색할 수 있는 근거를 제공할 수 있다는 점에 서, 본 연구에서는 설문조사 연구방법론을 사용하여 의사소통장 애 아동을 양육하고 치료하는 부모 및 전문가를 대상으로 수요자 의 요구를 반영한 '모바일 기반 의사소통능력 증진 콘텐츠'의 필요 성을 고찰하고자 한다. 본 연구 결과를 바탕으로 한국적 특성을 반 영한 언어중재 도구로서의 스마트폰의 가능성을 탐색하여, 스마트 폰 기술을 언어병리학 분야에 접목하는 사회적 컴퓨팅(social computing)을 실현하는 데에 기여하고자 한다.

본 연구는 의사소통장애 아동의 부모 및 전문가 집단의 스마트 폰 활용도를 알아보고, 의사소통장애 아동의 의사소통능력 증진 을 위해 필요로 하는 스마트폰콘텐츠의 종류와 요구도를 조사하여 실시간 부모교육 및 일상생활 통합형 중재 서비스의 가능성을 모색 하는 데 목적이 있다. 이를 위한 구체적인 연구문제는 다음과 같다.

첫째, 의사소통장애 아동의 부모 및 의사소통장애 전문가의 스 마트폰 활용도는 어떠한가?

둘째, 의사소통장애 아동의 부모 및 의사소통장애 전문가 간 의 사소통장애 아동의 의사소통능력 증진을 위해 필요하다고 생각하 는 스마트폰콘텐츠 종류에 차이가 있는가?

셋째, 의사소통장애 아동 부모의 자녀가 가진 의사소통 어려움 의 종류에 따른 스마트폰콘텐츠 종류별 요구도는 어떠한가?

넷째, 의사소통장애 아동 부모의 사회경제적 지위에 따른 부모 교육 요구도는 어떠한가?

\section{연구 방법}

\section{연구 대상}

본 연구는 현직 언어치료사와 언어치료를 받고 있는 의사소통장 애 아동의 부모, 또는 연구 참여를 희망한 어린이집에 다니고 있는 아동 중 현재 언어치료를 받고 있는 아동을 대상으로 하였으며, 연 구 대상에 대한 정보는 Table 1 에 제시하였다. 총 253 부의 설문지를 배부하였으며, 198 부(78.3\%)의 설문지가 회수되었다. 본 연구의 대상 이 되는 아동의 연령은 선행연구(Jung \& Yim, 2011; Kaiser \& Roberts, 2013; Roberts \& Kaiser, 2012) 결과를 참고하여 부모교육 프 로그램의 효과를 고려하여 2-5세로 하였으며, 자녀의 연령이 이에 해당되지 않는 부모의 설문지와 불충분하게 작성된 설문지는 분석 에서 제외함에 따라 총 189 부(74.7\%)의 설문지가 본 연구의 분석 자료가 되었다. 요건이 충족된 연구 대상자는 의사소통장애 전문 
Table 1. Participants information

\begin{tabular}{|c|c|c|c|}
\hline Classification & & & Frequency (\%) \\
\hline SLPs (N= 93) & $\begin{array}{l}\text { Gender } \\
\text { Certification }\end{array}$ & $\begin{array}{l}\text { Male } \\
\text { Female } \\
\text { 1st degree SLP } \\
\text { 2nd degree SLP } \\
\text { No Response or others } \\
\text { Seoul } \\
\text { Gyeonggi-do } \\
\text { Incheon } \\
\text { Chungcheong-do } \\
\text { Deajeon } \\
\text { Gyeongsang-do } \\
\text { Busan }\end{array}$ & $\begin{array}{c}4(4.3) \\
89(95.7) \\
38(40.9) \\
52(55.8) \\
3(3.3) \\
47(50.5) \\
31(33.3) \\
1(1.1) \\
3(3.2) \\
8(8.6) \\
1(1.1) \\
2(2.2)\end{array}$ \\
\hline Parents ( $\mathrm{N}=96$ ) & $\begin{array}{l}\text { Relationship with a } \\
\text { child } \\
\text { Age (yr) } \\
\text { Sex of a child } \\
\text { Age of a child (yr) }\end{array}$ & $\begin{array}{l}\text { Father } \\
\text { Mother } \\
\text { Others } \\
<30 \\
30-34 \\
35-39 \\
\geq 40 \\
\text { Male } \\
\text { Female } \\
2 \\
3 \\
4 \\
5 \\
\text { ID } \\
\text { PD/CP } \\
\text { ASD } \\
\text { HI } \\
\text { LI } \\
\text { FD } \\
\text { AD/PD } \\
\text { Others }\end{array}$ & $\begin{array}{c}4(4.2) \\
91(94.8) \\
1(1.0) \\
3(3.1) \\
32(33.3) \\
41(42.7) \\
20(20.8) \\
73(76.0) \\
23(24.0) \\
10(10.4) \\
31(32.3) \\
30(31.3) \\
18(18.8) \\
14(14.7) \\
12(12.6) \\
15(15.8) \\
10(10.5) \\
63(66.3) \\
1(1.1) \\
7(7.4) \\
5(5.3)\end{array}$ \\
\hline
\end{tabular}

$\mathrm{SLP}=$ speech language pathologist; $\mathrm{ID}=$ intellectual disorders; $\mathrm{PD} / \mathrm{CP}=$ physical disabilities or cerebral palsy; $A S D=$ autism spectrum disorders; $H I=$ hearing impairment; $\mathrm{LI}=$ language impairment; $\mathrm{FD}=$ fluency disorders; $\mathrm{AD} / \mathrm{PD}=$ articulation disorders or phonological disorders.

가 93 명, 의사소통장애 아동의 부모 96 명으로, 두 집단 모두 여성의 비율이 높았다(전문가 $95.7 \%$, 부모 93.8\%). 부모의 경우 96 명 중 91 명 (94.8\%)이 어머니였으며, 4 명은 아버지, 1 명은 할머니였다. 의사소통 에 어려움을 가진 자녀의 성별은 남자.(76.0\%)가 여자(24.0\%)보다 많았으며, 연령은 3세(32.3\%), 4세(31.3\%), 5세(18.8\%), 2세(10.4\%) 순 이었다. 자녀의 의사소통장애 유형은 국립특수교육원(Korea National Institute for Special Education, 2011)에서 발행한 '2011 특수 교육실태조사' 및 선행연구(Hong, 2013; Hwang \& Choi, 2012; Lee, Kang, \& Kim, 2013)를 참고하여 분류하였다. 기술통계 결과 언어 발달지연 및 지체(66.3\%)가 가장 많았고, 자폐범주성장애(15.8\%) 와 지적장애(14.7\%)가 그 뒤를 이었다. 본 연구에 참여한 의사소통 장애 전문가의 평균 연령은 31.56 세 $(\mathrm{SD}=7.351)$ 였으며, 임상 경력 은 2014년 3월 1일 기준 6년 2개월( $\mathrm{SD}=5$ 년 11개월)로 2개월부터
30년까지 다양하게 나타났다.

\section{연구 도구}

설문지는 언어치료 전문가용 설문지와 의사소통장애 아동의 부 모용 설문지 두 가지로 제작되었으며, 각각 (1) 스마트폰의 활용도(7 문항), (2) 의사소통능력 증진을 위한 스마트폰 어플리케이션 콘텐 츠 요구도(22문항), (3) 연구대상자 배경 정보(전문가용 12 문항, 부 모용 48 문항)를 묻는 세 영역으로 구성하였다. 응답 항목은 주로 선다형과 5점 척도형으로 설계하였으며, 응답자 사생활 침해 정도 가 적은 자기기입식(Heo, 2012)으로 설문조사를 시행하였다.

선행연구 및 기존의 검사도구에 수록된 의사소통기능 문항, 통 계청 자료를 참고하여 1 차로 설계한 설문지는 언어병리학과 교수 1 인과 1 급 언어치료사 1 인에게 내용의 타당성과 문항의 적절성을 검 증받았으며, 초안을 현재 언어치료를 받고 있는 3 세 아동의 어머니 1 인에게 사전 테스트를 실시하여 이를 토대로 설문지 구성을 개선 하고 어구를 다듬는 작업을 거쳤다. 언어치료사 2 인과 부모 2 인에 대한 사전 테스트 결과 최종적으로 완성된 설문지 작성에 소요되 는 시간은 전문가용은 약 5-10분, 부모용은 약 10-15분인 것으로 나 타났다. 본 연구에 사용된 전문가용 설문지와 부모용 설문지의 공 통 문항 중 일부를 Appendix에 제시하였다.

\section{전문가용 설문지}

언어치료 전문가용 설문지와 의사소통장애 아동의 부모용 설문 지는 (1) 스마트폰의 활용도와, (2) 의사소통능력 증진을 위한 스마 트폰 어플리케이션 콘텐츠요구도를 묻는 영역에 대해 동일한 설문 내용에 응답하도록 제작되었다. (1) 스마트폰의 활용도를 조사하는 영역은 방송통신위원회(Korea Communications Commission, 2013)의 '2012년 하반기 스마트폰 이용실태 조사'를 참고하여 설문 조사 대상자의 현재 스마트폰 이용 실태를 조사하기 위한 문항들 로 구성하였다. (2) 의사소통능력 증진을 위한 스마트폰 어플리케 이션 콘텐츠요구도에 대한 영역은 스마트폰 어플리케이션 중에서 특히 아동의 의사소통능력 증진을 위한 어플리케이션 사용 경험 에 대한 문항과, 스마트폰 어플리케이션 콘텐츠의 종류별로 조사 대상자가 필요 정도를 평가하는 문항으로 구성하였다. 의사소통기 능 증진을 위한 스마트폰 어플리케이션으로는 설문 문항에서 아동 용 멀티미디어(동영상, 동화 및 동요, 게임 등), 부모 교육(아동의 발 달 연령에 맞는 강의 동영상 및 사례에 대한 자료, 아동과의 의사소 통 시 올바른 대응 방법과 부모의 역할에 대한 조언 및 피드백 등 제공), 의사소통 보조 수단(그림 및 글자판 또는 말소리 출력기 등 을 통하여 아동의 의사소통 의도를 대신해주거나 돕는 어플리케이 
션 등)으로 보기를 제시하였으며, 이 외의 콘텐츠에 대해서는 '기타' 의 항목을 두어 설문조사 대상자가 자유롭게 기입할 수 있도록 하 였다. 스마트폰 어플리케이션 콘텐츠 종류별 필요성을 묻는 항목 은 총 11 개로, 발화의 양적인 정보(4문항)와 화용적 정보(3문항), 그 리고 부모교육 콘텐츠(4문항) 3 개 범주로 구성되었으며, 각 문항은 '전혀 필요없다'부터 '매우 필요하다'까지 5점 척도로 제시되었다. 이 중 발화의 양적인 정보에 대한 항목은 선행연구(Theimann-Bourque, Warren, Brady, Gilkerson, \& Richards, 2014)에서 사용된 영 유아 언어측정 도구(LENA)의 측정 항목을, 발화의 화용적 정보에 대한 항목은 영유아의 대화기술에 대한 선행연구(Lee \& Lee, 2013) 에서 자료 수집 시 측정한 항목을, 부모교육에 대한 항목은 Jung과 Yim (2011)의 메타연구 결과를 참고하여 구성하였다. 마지막으로 (3) 배경정보에 대한 영역에서는 언어치료사의 인구사회학적 정보 및 근무환경을 조사하였다.

\section{부모용 설문지}

의사소통장애 아동의 부모용 설문지는 (1) 스마트폰의 활용도와, (2) 의사소통능력 증진을 위한 스마트폰 어플리케이션 콘텐츠요구 도에 대한 영역은 전문가용 설문지와 동일하며, (3) 배경정보 영역 은 다르게 구성하였다. 아동의 장애유형과 아동과의 관계 등 기본 정보(8문항)와 치료기관에서의 부모교육과 관련한 문항(3문항), 그리고 자녀의 의사소통 문제에 대한 항목(37문항)으로 구성되었 으며, 학력 및 직업, 소득 등 사회경제적 속성은 응답자의 과민반응 을 방지하기 위하여 설문지의 제일 마지막에 삽입하였다. 이 중 부 모가 인식한 자녀의 의사소통 문제의 내용을 묻는 항목 37문항은 선행연구(Lee et al., 2013)에서 사용한 33개 문항에 영역 간 비율을 고려하여 선행연구(Lee \& Lee, 2013)를 참고한 담화(대화) 영역 4 문 항을 추가, 문항제시 순서 등을 수정하여 구성하였다. 해당 항목은 최종적으로 언어영역 11 문항, 담화(대화)영역 9 문항, 의사소통기능 9문항, 비언어적 의사소통영역 8 문항으로 구성되었으며, 각 문항은 '전혀 그렇지 않다'부터 '항상 그렇다'까지 5점 척도로 제시되었다. 본 항목의 신뢰도는 Cronbach's alpha $=.817$ 로, 문항 간 내적 신뢰 도는 높은 것으로 나타났다.

\section{연구 절차}

본 연구는 2014년 3월 말부터 4월 초에 걸쳐 서울 및 경기, 인천, 대전, 충청도, 부산, 제주도 소재 기관에 근무하는 언어치료사 및 기관 담당자에게 전화 또는 구두로 연구의 목적 및 내용에 대해 설 명하고, 설문조사 연구 참여에 동의한 언어치료사 및 기관을 대상 으로 설문지를 배부하였다. 의사소통장애 아동의 부모는 기관발
송 또는 해당 기관에서 언어치료사의 소개로 연구원이 직접 대면 하여 연구에 대해 설명한 후 설문지를 작성하도록 하거나, 해당 언 어치료사에게 협조를 요청하여 연구에 대한 설명문을 첨부한 부모 용 설문지를 배부하였다. 지리적 요건으로 인하여 직접 대면 설문 조사가 어려운 경우 연구 참여에 동의한 언어치료사 및 기관을 대 상으로 회신용 봉투를 동봉하여 설문지를 발송하거나 온라인을 통하여 설문조사를 실시하였다. 작성된 설문지는 연구원이 직접 방문하여 수거하거나 전화로 요청하여 회수율을 높이고자 하였다.

\section{자료 처리}

본 연구에서 수집된 자료의 분석을 위하여 IBM SPSS Statistics version 19 (SPSS Inc., Chicago, IL, USA)을 이용하였다. 조사 대상 자의 기본정보 및 각 설문 문항에 대한 응답에 대하여 빈도와 백분 율을 함께 산출하였다. 조사 대상자 및 범주 간 응답차이를 분석하 기 위하여 카이제곱(chi-square) 검정과 분산분석(ANOVA)을 실 시하였으며, 부모의 사회경제적 특징과 부모교육 요구도 간 관련성 을 검토하기 위하여 Pearson 상관분석을 실시하였다.

\section{연구 결과}

\section{의사소통장애 아동의 부모 및 전문가의 스마트폰 활용 현황}

의사소통장애 아동의 부모 및 전문가 189 명을 대상으로 하루 평 균 스마트폰 이용 시간을 조사한 결과 평균 217.44분 $(\mathrm{SD}=214.170)$ 으로, 응답자들은 하루에 약 3.6 시간 동안 스마트폰을 이용하는 것 으로 나타났다. 이는 2012년 방송통신위원회와 한국인터넷진흥원 에서 12-59세 남녀 4,000명을 대상으로 실시한 설문조사 결과인 하 루 평균 3.4시간과 큰 차이가 없었다. 스마트폰을 통해 주로 이용하 는 기능 가운데 응답자들이 1순위로 꼽은 것은 문자메시지 및 SNS (43.4\%), 무선인터넷 및 어플리케이션(32.8\%), 음성 및 영상통화 (23.8\%) 순으로 나타나, 응답자들은 스마트폰을 기존의 휴대 전화 가 가졌던 통화 기능보다는 텍스트 형식의 의사소통 수단 또는 무 선인터넷 및 스마트폰에서 제공하는 응용 프로그램 실행을 목적으 로 더욱 많이 사용하는 것으로 조사되었다.

아동의 의사소통능력 증진을 위한 스마트폰 어플리케이션 사용 경험을 묻는 질문에 의사소통장애 아동의 부모는 $52.1 \%$ (50/96), 전문가는 67.7\% (63/93)가 '있다’고 대답하였으며, 카이제곱 검정 결 과 집단 간 차이가 유의한 것으로 나타났다 $\left(\chi^{2}(1)=4.818, p<.05\right)$. 즉, 전문가 집단의 사용 경험이 부모 집단보다 통계적으로 유의하 게 높았다. 해당 어플리케이션이 아동의 의사소통능력 증진에 어 느 정도 영향을 미쳤는지에 대해서 전문가는 '다소 도움이 되었다 
(49.2\%)', '많은 도움이 되었다(6.3\%)'는 응답이 과반수를 차지하였 으나, 부모의 경우 ‘큰 영향이 없었다(16.0\%)'와 '영향이 미비하다 (46.0\%)'는 의견이 과반수로 나타났다. 한편 두 집단 모두 대상자의 연령에 따른 아동의 의사소통능력 증진을 위한 스마트폰 어플리케
이션 사용 경험은 유의한 차이가 없는 것으로 나타났다.

아동의 의사소통능력 증진을 위한 스마트폰 어플리케이션 사용 경험이 있는 응답자에게 해당 어플리케이션의 종류를 조사하였다 (복수응답 허용). 부모가 사용한 의사소통능력 증진 어플리케이션

Table 2. Response for the needs of contents to improve communication skills

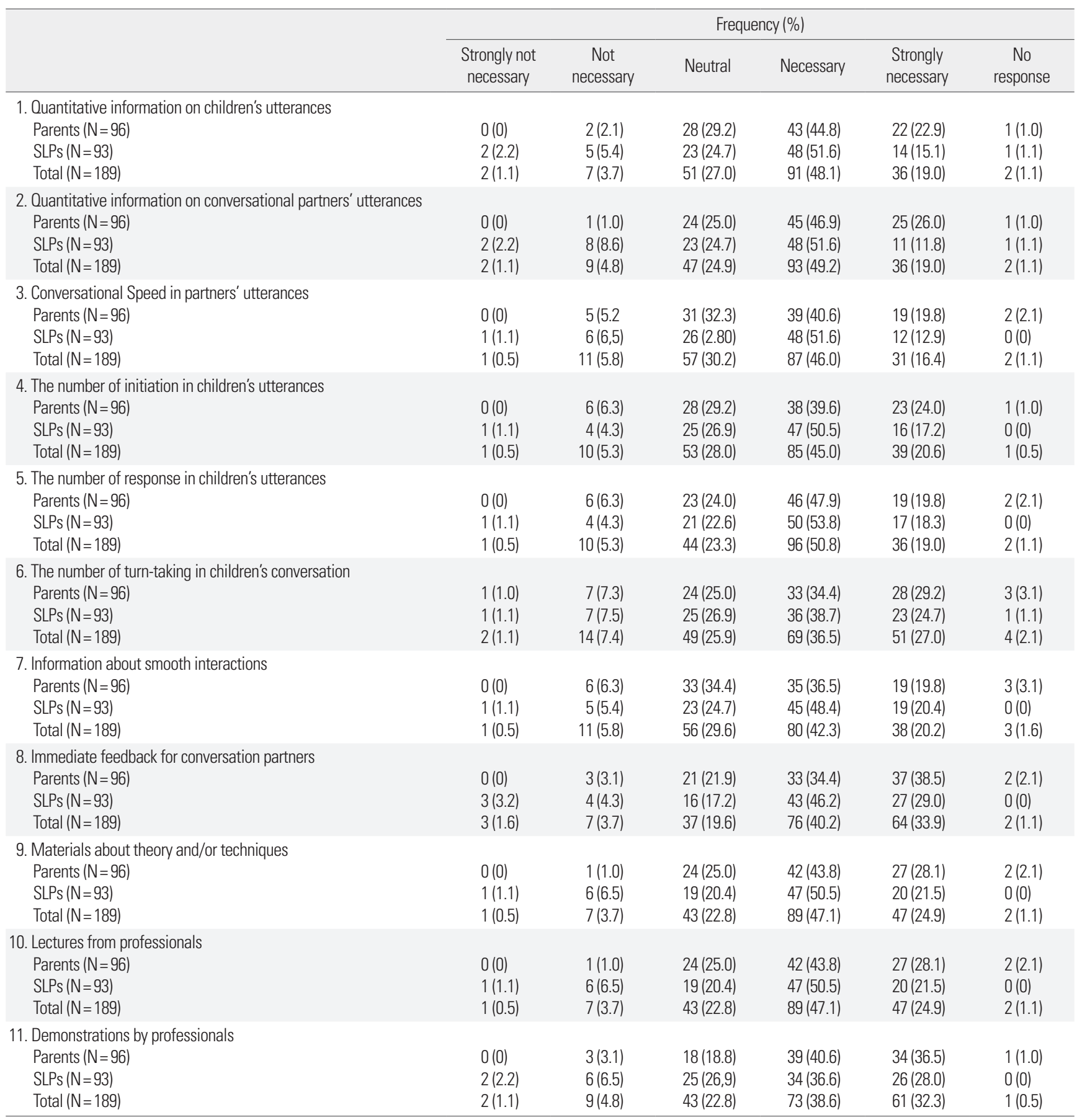

Values are presented as mean (SD).

$S L P=$ speech language pathologist. 
은 아동용 멀티미디어(93.9\%), 의사소통 보조 수단(22.4\%), 부모교 육(20.4\%) 순으로 나타났고, 전문가는 아동용 멀티미디어(88.9\%), 의사소통 보조수단(46.0\%), 부모교육(7.9\%) 순으로 나타났다. 두 집단 모두 주로 의사소통장애 아동에게 동영상 및 동화·동요, 게 임 등의 멀티미디어를 보여주는 기능의 스마트폰 어플리케이션을 이용하는 것으로 조사되었다. 또한 각 항목별로 집단 간 차이를 카 이제곱 검정으로 비교한 결과 의사소통 보조수단에서 유의한 차 이를 보여 $\left(\chi^{2}(1)=7.040, p<.05\right)$, 전문가 집단이 부모에 비해 의사소 통 보조수단으로서 스마트폰 어플리케이션을 유의하게 많이 사용 하는 것으로 나타났다.

\section{의사소통장애 아동의 부모 및 전문가 간의 의사소통능력 증진 스마트폰콘텐츠 요구도}

의사소통능력 증진을 위한 스마트폰 어플리케이션 콘텐츠 11 개 종류에 대한 요구도를 Table 2에 제시하였다. 콘텐츠의 필요성에 대 해 긍정적인 답변(필요하다, 매우 필요하다)을 한 응답자를 기준으 로 살펴보면 부모 집단(73\%)과 전문가 집단(70\%) 모두 공통적으로 전문가의 시범에 대한 요구도가 높았으며, 부모 집단은 의사소통 상황에서 아동의 대화 상대자의 발화에 대한 양적인 정보를 제공 하는 콘텐츠( $70 \%)$ 와 대화 상대자에게 실시간 피드백을 제공하는 콘텐츠(70\%)가 후순위로 나타났고, 전문가 집단은 대화 상대방에 게 실시간 피드백을 제공하는 콘텐츠(70\%)에 이어 아동의 반응 횟 수에 대한 정보(67\%)와 전문가의 강의(67\%) 및 이론 및 기술에 대 한 자료(67\%)에 대한 요구도가 높게 나타났다. 본 문항은 발화의 양 적 정보에 대한 항목 $(1,2,3,7)$ 과 발화의 화용적 정보에 대한 항목 $(4,5,6)$, 그리고 부모교육 콘텐츠에 대한 항목 $(8,9,10,11)$ 의 세 가 지 범주로 분류할 수 있는데, 두 집단 모두 부모교육 콘텐츠에 대한 요구도가 높게 나타났다.

의사소통능력 증진을 위한 스마트폰 어플리케이션 콘텐츠 종류 별 요구도의 집단 간 차이는 Fisher의 정확한 검정 결과 ‘의사소통 상황에서 아동의 대화 상대자(부모 등)의 발화에 대한 양적인 정보 를 제공하는 콘텐츠'에서만 유의하게 나타났다 $(p<.05)$. 이 문항에 대해 전문가는 '필요하다(51.6\%)'와 '매우 필요하다(11.8\%)'의 긍정 적 답변이 63.4\% (59/93)로 나타났으며, 부모는 '필요하다(46.5\%)'와 '매우 필요하다(26.0\%)'의 답변이 $72.9 \%$ (70/96)로 나타났다. 즉 아 동과 대화할 때 아동의 대화 상대자로서의 부모는 본인 발화의 양, 발화 유지 시간 등에 대한 정보를 필요로 하였다. 따라서 부모 자신 의 발화 조절 필요성을 인식하고 있음을 확인할 수 있다.

앞서 언급한 바와 같이 본 문항은 발화의 양적 정보에 대한 항목 (범주 1), 발화의 화용적 정보에 대한 항목(범주 2), 부모교육 콘텐
Table 3. Desired categories needs for a smartphone application to improve communication skills (five-point scale with a maximum score of 5 )

\begin{tabular}{lccc}
\hline & $\begin{array}{c}\text { Quantitative informa- } \\
\text { tion on utterances }\end{array}$ & $\begin{array}{c}\text { Pragmatic informa- } \\
\text { tion on utterances }\end{array}$ & $\begin{array}{c}\text { Education contents } \\
\text { for parents }\end{array}$ \\
\hline Parents & $3.419(.618)$ & $3.757(.905)$ & $4.081(.839)$ \\
SLPs & $3.159(.522)$ & $3.817(.775)$ & $3.954(.750)$ \\
Total & $3.291(.586)$ & $3.787(.842)$ & $4.018(.797)$ \\
\hline
\end{tabular}

Values are presented as mean (SD).

츠에 대한 항목(범주3)의 세 개 범주로 나눌 수 있다. 각 범주별 5점 척도의 평균값은 Table 3에 제시하였다. 각 범주별로 집단 간 차이 를 분석한 결과 범주 1 에서만 유의한 차이가 나타나 $\left(F_{(1,187)}=9.695\right.$, $p<.005)$, 발화의 양적 정보에 대한 콘텐츠 요구도가 전문가 집단에 비해 부모 집단에서 유의하게 높은 것으로 나타났다.

응답자들의 요구도가 각 범주 간 차이가 있는지 검증한 결과, 전체 집단에서 3 개 범주 간 차이가 유의하였다 $\left[F_{(2,374)}=92.552, p<.001\right]$. 이에 대해 Bonferroni 사후검정을 실시한 결과 3 개 범주 각각의 차 이가 모두 유의한 것으로 나타났다 $(p<.005)$. 즉, 의사소통증진을 위한 스마트폰 어플리케이션 콘텐츠에 대한 요구도는 부모교육 콘 텐츠가 가장 높고, 발화의 화용적 정보와 발화의 양적 정보 순인 것 으로 나타났다. 또한 집단과 범주 간 이차상호작용이 유의한 것으 로 나타나, 이에 대한 사후검정으로 MMATRIX와 LMATRIX를 사용한 상호작용 대비검정을 실시하였다. 그 결과 범주 2 (발화의 화용적 정보)와 범주 3 (부모교육 콘텐츠)에서의 그룹 간 차이는 유 의하지 않았으나, 범주 1 (발화의 양적 정보)에서의 그룹 간 차이는 유의한 것으로 나타났다 $\left[F_{(1,187)}=15.038, p<.001\right]$. 즉, 상호작용 효 과가 유의하였던 것은 발화의 양적 정보 콘텐츠에 대한 요구도가 전문가에 비해 부모가 유의하게 높은 것에서 기인한 것으로 보인다.

\section{의사소통장애의 유형에 따른 의사소통능력 증진 스마트폰콘텐츠 요구도}

부모가 인식한 자녀의 의사소통의 어려움에 대한 정보는 Table 4 및 Figure 1과 같다. 부모가 인식한 자녀의 의사소통 어려움이 언어 영역에서 나타나는 경우(언어 영역 평균>3) 필요로 하는 의사소통 능력 증진 스마트폰콘텐츠는 전문가의 시범( $\mathrm{M}=4.35, \mathrm{SD}=1.01)$, 전문가의 강의 $(\mathrm{M}=4.16, \mathrm{SD}=1.05)$, 그리고 대화 상대자의 발화에 대한 양적인 정보 $(\mathrm{M}=4.08, \mathrm{SD}=.70)$ 순으로 나타났으며, 담화.대 화 영역인 경우(담화.대화 영역 평균>3) 전문가의 시범 $(\mathrm{M}=4.18$, $\mathrm{SD}=1.08)$, 전문가의 강의 $(\mathrm{M}=4.00, \mathrm{SD}=.94)$, 부모에게 실시간 피 드백 제공 $(\mathrm{M}=3.87, \mathrm{SD}=1.11)$ 순으로 나타났다. 또한 자녀의 의사 소통 어려움의 영역이 의사소통기능인 경우(의사소통기능 영역 평 
Table 4. Needs for a smartphone application based on types of children's communication difficulties

\begin{tabular}{|c|c|c|c|c|}
\hline & \multicolumn{4}{|c|}{ Sections of communication difficulties } \\
\hline & $\begin{array}{l}\text { Language } \\
(\mathrm{N}=49)\end{array}$ & $\begin{array}{l}\text { Discourses } \\
(\mathrm{N}=62)\end{array}$ & $\begin{array}{l}\text { Communicative skills } \\
\qquad(\mathrm{N}=37)\end{array}$ & $\begin{array}{l}\text { Nonlinguistic communication } \\
\qquad(\mathrm{N}=64)\end{array}$ \\
\hline Quantitative information on children's utterances & $3.98(.78)$ & $3.71(.88)$ & $3.70(.909)$ & $3.75(.91)$ \\
\hline Quantitative information on conversational partners' utterances & $4.08(.70)$ & $3.82(.86)$ & $3.81(.920)$ & $3.88(.88)$ \\
\hline Conversational speed in partners' utterances & $3.73(1.00)$ & $3.56(1.05)$ & $3.62(.907)$ & $3.61(1.09)$ \\
\hline The number of initiation in children's utterance & $3.78(.94)$ & $3.85(.94)$ & $3.70(.888)$ & $3.77(1.00)$ \\
\hline The number of response in children's utterances & $3.69(1.00)$ & $3.69(1.02)$ & $3.62(.902)$ & $3.66(1.07)$ \\
\hline The number of turn-taking in children's conversation & $3.69(1.29)$ & $3.60(1.26)$ & $3.46(1.087)$ & $3.69(1.26)$ \\
\hline Information about smooth interactions & $3.61(1.19)$ & $3.42(1.15)$ & $3.46(.985)$ & $3.61(1.15)$ \\
\hline Immediate feedback for conversation partners & $4.04(1.06)$ & $3.87(1.11)$ & $3.73(1.000)$ & $4.06(1.08)$ \\
\hline Materials about theory and/or techniques & $3.82(.93)$ & $3.74(.97)$ & $3.78(.913)$ & $3.91(1.02)$ \\
\hline Lectures from professionals & $4.16(1.05)$ & $4.00(.94)$ & $3.89(.961)$ & $4.14(.96)$ \\
\hline Demonstrations by professionals & $4.35(1.01)$ & $4.18(1.08)$ & $4.05(.952)$ & $4.31(1.07)$ \\
\hline
\end{tabular}

Values are presented as mean (SD).

Table 5. Cooperation between parents and clinics based on parents' response

\begin{tabular}{lccccccc}
\hline & & & & & Frequency $(\%)$ \\
\cline { 2 - 7 } & $\begin{array}{c}\text { Parental } \\
\text { education }\end{array}$ & $\begin{array}{c}\text { Parental } \\
\text { consultation }\end{array}$ & $\begin{array}{c}\text { Written } \\
\text { information }\end{array}$ & $\begin{array}{c}\text { Lectures and/or } \\
\text { open forums }\end{array}$ & None & Others & No response \\
\hline Parents $(\mathrm{N}=96)$ & $9(9.4)$ & $75(78.1)$ & $1(1.0)$ & $0(0)$ & $4(4.2)$ & $0(0)$ & $7(7.3)$ \\
\hline
\end{tabular}

Values are presented as mean (SD).

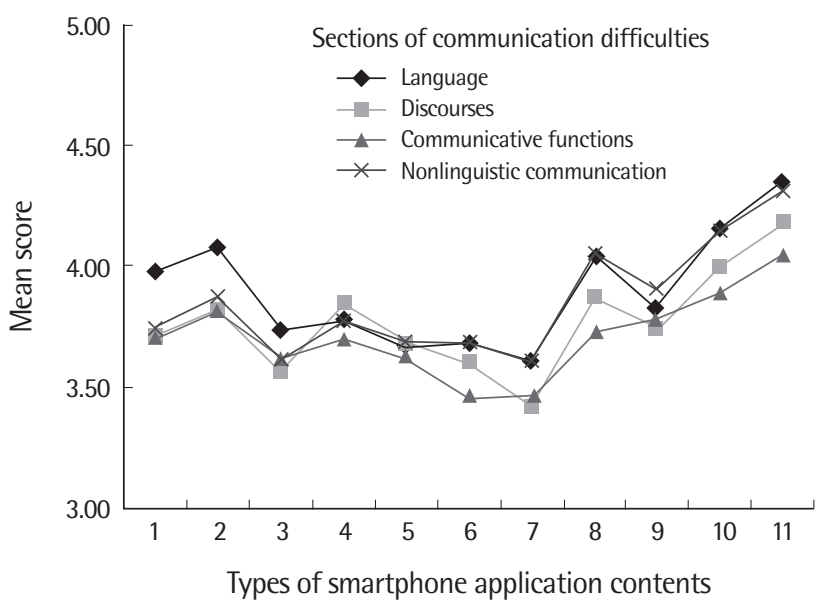

Figure 1. Parents desired educational content in a smartphone application. 1 = Quantitative information on children's utterances; $2=$ Quantitative information on conversational partners' utterances; $3=$ Conversational speed in partners' utterances; $4=$ The number of initiation in children's utterances; $5=$ The number of response in children's utterances; $6=$ The number of turn-taking in children's conversation; $7=$ Information about smooth interactions; $8=$ Immediate feedback for conversation partners; $9=$ Materials about theory and/or techniques; $10=$ Lectures from professionals; $11=$ Demonstrations by professionals .

균>3)는 전문가의 시범 $(\mathrm{M}=4.05, \mathrm{SD}=1.25)$, 전문가의 강의 $(\mathrm{M}=$ $3.89, \mathrm{SD}=1.08)$, 대화 상대자의 발화에 대한 양적인 정보 $(\mathrm{M}=3.81$,
$\mathrm{SD}=.97$ ) 순으로, 비언어적 의사소통인 경우(비언어적 의사소통 영 역 평균>3) 전문가의 시범 $(\mathrm{M}=4.31, \mathrm{SD}=1.07)$, 전문가의 강의 $(\mathrm{M}=$ $4.14, \mathrm{SD}=.96)$, 아동의 대화 상대자에게 피드백 제공 $(\mathrm{M}=4.06, \mathrm{SD}$ $=1.02)$ 순으로 나타났다. 그런데 대화 상대자의 양적인 정보에 대한 콘텐츠는 자녀의 의사소통 어려움의 영역이 담화.대화인 경우에 서는 4 번째 $(\mathrm{M}=3.82, \mathrm{SD}=.86)$, 비언어적 의사소통인 경우에서는 5 번째 $(\mathrm{M}=3.88, \mathrm{SD}=.88)$ 로 나타난 바, 대화 상대자의 양적인 정보 에 대한 요구도는 자녀의 의사소통 어려움의 영역과 상관없이 높은 편이라고 할 수 있다. 분산분석 결과 문항별 집단 간 차이는 유의하 지 않았다.

\section{의사소통장애 아동 부모의 부모교육 요구도}

치료기관과 의사소통장애 아동 부모 간 협력 현황을 파악하기 위하여 조사한 결과, 부모의 경우 부모상담(78.1\%)을 가장 많이 받 고 있는 것으로 나타났으며(Table 5), 전문가의 경우에도 마찬가지 (94.6\%)였다(Table 6). 의사소통장애 전문가의 경우 치료기관 및 치 료 대상자의 특성에 따라 적절한 방식의 협력 방식을 선택할 것이 므로, 복수응답을 허용하였다.

한편, 의사소통장애 아동의 부모는 부모교육의 필요성에 대하여 '필요하다'는 의견이 $42.7 \%$ (41/96), '매우 필요하다'는 의견이 $36.5 \%$ 
Table 6. Cooperation between parents and clinics based on SLPs' responses

\begin{tabular}{lccccccc}
\hline & \multicolumn{4}{c}{ Frequency $(\%)$} \\
\cline { 2 - 7 } & $\begin{array}{c}\text { Parental } \\
\text { education }\end{array}$ & $\begin{array}{c}\text { Parental } \\
\text { consultation }\end{array}$ & $\begin{array}{c}\text { A guideline for } \\
\text { home study }\end{array}$ & $\begin{array}{c}\text { Lectures and/or } \\
\text { open forums }\end{array}$ & None & Others & No response \\
\hline SLPs $(\mathrm{N}=162)$ & $28(30.4)$ & $87(94.6)$ & $43(46.7)$ & $1(1.1)$ & $2(2.2)$ & $1(1.1)$ & $0(0)$ \\
\hline
\end{tabular}

Values are presented as mean (SD).

$\mathrm{SLP}=$ speech language pathologist.

(35/96)로 나타났으며, '전혀 필요없다'와 '필요없다’는 각각 $0 \%(0 / 96)$ 와 $1 \%(1 / 96)$ 로 나타나 부모교육이 필요하다고 생각하는 응답자가 $79.2 \%$ (76/96)에 달했다. 부모의 사회경제적 지위는 최종학력과 평 균 연소득으로 분류하였으며, 최종학력은 7 개 척도(초졸 이하, 중 졸, 고졸, 2 년제 대졸, 4 년제 대졸, 석사, 박사)의 부모 평균으로 조사 하였을 때 2년제 대졸에서 4년제 대졸 사이가 과반(54.7\%)으로, 평 균 연소득은 3,000-5,000만원(37.1\%), 5,000-7,000만원(25.8\%)인 가 정이 과반으로 나타났다. 부모의 사회경제적 지위와 부모교육 요구 도 간 상관관계를 검토하기 위하여 Pearson 상관분석을 실시하였으 나, 사회경제적 지위를 산출하기 위한 최종학력 및 평균 연소득과 부모교육 요구도와의 상관관계는 유의하지 않은 것으로 나타나, 부 모의 사회경제적 지위와 무관하게 의사소통장애 아동의 부모는 부 모교육의 필요성을 인식하고 있는 것으로 조사되었다.

\section{논의 및 결론}

본 연구는 의사소통장애 아동의 의사소통능력 증진을 위한 스 마트폰의 가능성을 탐색하고자 의사소통장애 아동의 부모 및 전 문가를 대상으로 일상생활에서의 스마트폰의 활용도를 스마트폰 이용 시간으로 알아보고, 의사소통장애 아동의 부모와 전문가 간 요구하는 스마트폰콘텐츠 종류에 차이가 있는지, 또한 의사소통 장애 아동 부모의 경우 자녀의 의사소통 어려움의 유형에 따른 스 마트폰콘텐츠 종류에 차이가 있는지 조사하였다. 또한 의사소통 장애 아동 부모의 부모교육 요구도를 검토하여 스마트폰이 가진 휴 대성, 접근 용이성을 부모교육에 활용할 수 있는 가능성을 탐색하 고자하였다.

본 연구의 결과는 스마트 미디어 사회를 살아가고 있는 의사소통 장애 아동의 부모 및 전문가의 스마트폰 활용 현황 및 콘텐츠 요구 사항을 파악하는 기초 자료로서의 의의를 갖는다. 본 연구의 대상 이 된 의사소통장애 아동의 부모와 전문가들은 2012년 방송통신 위원회와 한국인터넷진흥원에서 실시한 대규모 설문조사 연구 결 과와 비슷한 스마트폰 사용량을 보여, 스마트폰 사용에 있어서 대 한민국 성인 일반의 대표성을 갖는다고 할 수 있다. 아동의 의사소
통능력 증진을 위한 스마트폰 어플리케이션 콘텐츠를 11 가지로 제 시한 문항 가운데 집단 간 차이가 유의하였던 것은 '의사소통 상황 에서 아동의 대화 상대자(부모 등)의 발화에 대한 양적인 정보를 제공하는 콘텐츠'로서, 부모 집단의 요구도가 유의하게 높은 것으로 나타났다. 자녀의 의사소통 어려움 유형에 따라 필요로 하는 의사 소통능력 증진 스마트폰콘텐츠는 집단별 순위에서 다소 차이는 있 었지만, 문항에 따른 집단 간 차이는 유의하지 않았다. 의사소통장 애 아동의 부모가 느끼는 부모교육의 필요성에 대하여는 응답자의 79.2\%가 ‘필요하다(42.7\%)' 또는 '매우 필요하다(36.5\%)'고 대답하 였으며, 부모의 사회경제적 지위와의 상관관계는 나타나지 않았다.

연구 대상자인 의사소통장애 아동의 부모와 전문가들은 스마트 폰을 음성 및 영상 통화보다 무선인터넷 및 어플리케이션 실행을 목적으로 더욱 많이 사용하고 있었다. 특히 아동의 의사소통능력 증진을 위한 스마트폰 어플리케이션 사용 경험은 두 집단 모두 과 반수가 '있다'고 응답하였으며, 전문가 집단이 부모 집단에 비해 유 의하게 높은 비율인 것으로 나타났다. 해당 어플리케이션이 아동 의 의사소통능력 증진에 도움이 되었는지에 관하여는 부모 집단은 부정적인 의견이 과반수였던 반면, 전문가 집단은 긍정적인 의견이 과반수였으나, 통계적으로 유의한 차이를 보이지는 않았다. 아동의 의사소통능력 증진을 위해 사용한 어플리케이션 종류는 두 집단 모두 아동용 멀티미디어가 가장 높은 비율로 나타났으며, 의사소 통 보조수단은 두 집단 모두 2순위로 나타났으나 집단 간 통계적으 로 유의한 차이를 보였다. 즉, 의사소통 보조수단으로서의 어플리 케이션을 전문가 집단이 부모 집단에 비해 많이 사용하였으며, 이 러한 어플리케이션을 치료에 활용함으로써 아동의 의사소통능력 증진에 긍정적인 경험을 한 전문가 집단에서 어플리케이션 사용 빈 도가 높게 나타난 것으로 보인다.

의사소통장애 아동의 부모 및 전문가 집단이 필요로 하는 콘텐 츠를 문항별로 살펴보면, 두 집단 모두 전문가가 시범을 보이는 콘 텐츠를 1 순위로 꼽았으며, 전체적으로는 아동의 대화 상대방(성인) 에게 실시간 피드백을 제공하는 콘텐츠에 대한 요구도가 가장 높 았다. 11 개 항목 가운데 전문가 집단의 경우 전문가가 정보를 제공 하는 형식의 콘텐츠가 1-2순위로 나타났으며, 부모 집단의 경우 아 
동의 대화 상대방(성인)의 양적인 정보를 제공하는 콘텐츠와 실시 간 피드백을 제공하는 콘텐츠가 전문가의 시범에 이어 후순위로 나타난 것이 특징적이다. 이러한 결과는 전문가가 여러 가지 형태의 이론적·경험적 교수 자료를 수요자에게 제공해주고 또 공유하기 를 원한다면, 의사소통장애 아동의 부모는 전문가가 아동과의 상 호작용 상황에서의 대응 방법을 시연하여 보여주거나 또는 자녀와 의 의사소통 상황에서 자신의 발화에 대한 계량적인 정보를 실시 간으로 제공받고 점검받기를 원한다는 것을 보여준다. 의사소통장 애 아동과 부모를 대상으로 중재를 제공하는 자로서의 전문가는 수요자가 원하는 바가 무엇인지 염두에 두어야 할 것이다. 최근 개 발된 TalkBetter라는 프로그램은 부모와 아동이 상호작용을 하는 동안 부모에게 실시간으로 부모의 발화 정보에 대한 피드백을 제공 하여 부모가 자신의 반응성, 발화 속도 등을 조절함으로써 아동이 발화를 산출하는 것에 도움을 줄 수 있음을 확인하였다(Hwang, Huang, \& Hsu, 2014). 이 프로그램은 개발 단계로서 아직 보급화되 지 않았으나, 이러한 맥락의 프로그램을 스마트폰 어플리케이션으 로써 접근성을 높여 보급할 수 있다면 아동의 언어 환경에 대해 정 보를 제공함과 동시에 의사소통장애 아동의 조기 선별의 도구로서 가정 및 임상에서 유용하게 사용될 수 있을 것이다.

아동의 의사소통능력 증진을 위한 스마트폰 어플리케이션 콘텐 츠를 발화의 양적 정보에 대한 문항, 발화의 화용적 정보에 대한 문 항, 그리고 부모교육 콘텐츠에 대한 문항의 세 가지 범주로 분류하 여 살펴보았을 때 의사소통장애 아동의 부모 및 전문가 두 집단 모 두 부모교육 콘텐츠에 대한 요구도가 가장 높았으며, 그 다음으로 발화의 화용적 정보에 대한 콘텐츠와 발화의 양적 정보에 대한 콘 텐츠 순이었다. 그런데 발화의 양적 정보에 대한 콘텐츠의 경우 두 집단 간 차이가 유의한 것으로 나타나, 아동과의 대화 상황에서 아 동과 그 대화 상대자(부모 등)의 발화의 양, 발화 유지 시간, 발화 속 도, 발화 비율 등 양적인 정보에 대한 부모의 요구도가 전문가에 비 해 높은 것으로 나타났다. 이는 자녀의 의사소통 어려움의 유형에 따른 부모의 스마트폰 어플리케이션 콘텐츠요구도를 분석하였을 때, 모든 하위집단에서 1-2순위로 꼽힌 전문가의 강의 및 시범에 이 어, 자녀가 언어영역에 어려움을 보이는 부모 집단과 의사소통기능 영역에 어려움을 보이는 부모 집단에서는 3순위, 담화.대화 영역에 어려움을 보이는 집단에서는 4순위, 비언어적 의사소통 영역에 어 려움을 보이는 집단에서는 5순위로 나타난 것과도 일맥상통한다. 즉, 의사소통장애 아동의 부모는 자녀와의 의사소통 상황에서 양적 인 정보에 대한 필요성을 인식하고 있음을 보여주는 결과라 하겠다.

의사소통장애 아동의 부모 및 전문가 집단 모두 스마트폰 어플 리케이션 중 부모교육 콘텐츠에 대한 요구도가 높게 나타난 바, 부
모교육의 현황 및 요구도를 검토하였다. 부모의 사회경제적 지위와 무관하게 의사소통장애 아동의 부모는 부모교육의 필요성에 동의 하는 의견이 $79.2 \%$ 에 달했으나, 의사소통장애 아동의 부모와 치료 기관과의 협력은 주로 부모상담을 위주로 진행되고 있는 것으로 조 사되었다. 부모교육은 치료시간의 감소에 따른 비용 절감과, 실질 적으로 가정에까지 치료가 연장되어 장시간 치료서비스를 제공할 수 있다는 장점이 있다(Lee \& Seok, 2007). 부모와의 협력 프로그램 을 제공하는 주체가 되는 치료기관에서는 상담 외에 아동의 발달 연령에 맞는 강의 및 사례에 대한 교육, 아동과의 의사소통 시 대응 방법과 부모의 역할에 대한 조언 및 피드백을 제공하는 교육 프로 그램에 대한 보다 적극적인 접근이 필요할 것이다.

본 설문조사 결과 의사소통장애 아동의 부모 및 전문가들은 스 마트 미디어 사회의 일원으로서 스마트폰 어플리케이션을 아동의 의사소통능력 증진을 위한 도구로 사용하고 있음을 확인하였다. 또한 스마트폰 어플리케이션을 통하여 얻고자 하는 콘텐츠의 종류 를 부모와 전문가 집단을 비교하여 검토한 결과, 부모교육 관련 콘 텐츠의 요구도가 높았으며, 특히 부모의 경우 발화의 양적인 정보 에 대한 요구도가 높게 나타났다. June와 Back (2004)의 연구에 의 하면 장애 아동 부모는 출산 후 장애의 발견 및 진단, 장애의 특성 등에 대해 다양한 경로로 획득한 정보가 도움이 되었다고 응답하 였으며, 부모의 역할 및 조기교육기관에 대한 정보도 도움이 되었 다고 응답한 바 있다. 이 연구에서도 마찬가지로 장애 아동 부모가 인식하는 부모의 역할과 조기교육 및 치료 기관에 대한 정보의 필 요성이 높게 나타난 바, 본 연구와 일치하는 결과이며 장애아동 부 모가 필요로 하는 요구 사항이 수년간 변함없음을 시사한다. 또한 소아과 병동의 어머니에게 아동의 현 상태에 대한 정보가 정확히 제공되지 않았을 때 어머니의 대처 및 문제해결 능력이 낮았음을 밝힌 선행연구(Yoo, 2007)가 시사하는 바와 같이 임상에서 부모에 게 시의적절한 정보를 제공하는 것은 중요하다. 따라서 앞으로는 의사소통장애 아동의 중요한 의사소통 상대방인 두 집단의 요구 를 반영한 스마트폰 어플리케이션을 개발하여 일상생활에서 충분 히 활용될 수 있을 가능성을 모색해볼 때이다.

효과적인 의사소통장애의 치료를 위해 가장 기본적이고 중요한 요소로 꼽히는 것은 조기 진단이다(Moeller, 2000). 특히 유아기는 각종 선별 검사와 조기선별에 따른 조기 중재가 시작될 수 있다는 점에서 중요하다(Kim \& Hwang, 2013). Ward (1999)의 연구에 의 하면 1 세에 조기선별을 통한 조기치료를 받은 유아의 경우 3 세에 언어발달지체로 진단받는 비율이 조기치료를 받지 않은 집단에 비 해 유의하게 낮게 나타난 바 있다. 이처럼 적기에 정확한 진단을 통 해 이루어지는 의사소통장애 전문가의 개입이 치료 효과를 극대화 
시킬 수 있으므로, 위험군에 대한 선별 과정을 통한 선제적인 대응 이 필요하다. 본 연구의 결과를 토대로, 언어치료의 수요자와 공급 자의 요구를 반영한 스마트폰 어플리케이션을 개발하여 의사소통 장애의 선별 또는 치료의 도구로 사용할 수 있는 가능성을 모색하 는 후속 연구가 필요할 것이다. 또한 스마트폰을 사용하는 성인의 연령 및 대상 아동의 연령이 스마트폰을 비롯한 스마트 미디어에 대한 친숙도와 활용 방식에 영향을 미칠 수 있으므로, 여러 연령층 에 유용한 스마트폰 어플리케이션 개발을 위해서는 이에 대한 심 도 있는 후속 연구가 따라야 할 것으로 보인다.

본 연구는 의사소통장애 아동의 부모와 현직 언어치료사를 대 상으로 하였는데, 언어치료실에 아동을 데리고 오는 사람이 주로 엄마이며, 또한 언어치료사라는 직업적 특성상 연구 대상자의 성별 이 여성에 편중되어 있다는 제한점이 있다. 부모의 경우 자녀의 장 애 유형이 언어발달지연 및 지체인 경우가 과반을 차지하고, 복수 응답을 허용한 것을 감안하더라도 다른 장애 유형 간의 분포가 고 르지 않으며, 전문가의 경우 근무지가 서울 및 경기권에 치중되어 있다는 한계점이 있다. 이러한 연구 대상의 표집 및 집단구성에의 제한점은 연구 결과의 신뢰도를 저하시킬 수 있는 바, 연구 대상자 의 성별과 장애 유형 및 지역을 균형화한 후속연구가 필요할 것으 로 보인다.

\section{REFERECES}

Breitenstein, S. M., \& Gross, D. (2013). Web-based delivery of a preventive parent training intervention: a feasibility study. Journal of Child and Adolescent Psychiatric Nursing, 26, 149-157.

Buckingham, D. (2013). Media education: literacy, learning and contemporary culture. Hoboken, NJ: John Wiley \& Sons.

Cafiero, J. M., \& Meyer, A. (2008). Your child with autism: when is augmentative and alternative communication (AAC) an appropriate option? Exceptional Parent, 38, 28-30.

Caskey, M., \& Vohr, B. (2013). Assessing language and language environment of high-risk infants and children: a new approach. Acta Paediatrica, 102, 451-461.

Caskey, M., Stephens, B., Tucker, R., \& Vohr, B. (2011). Importance of parent talk on the development of preterm infant vocalizations. Pediatrics, 128 , 910-916.

Cho, Y. S. (2011). The future of IT service on smart media. In SMART on ICT 2011 Conference Presentation. Seoul: Korea Education and Research Information Service.
Crais, E. R., Roy, V. P., \& Free, K. (2006). Parents' and professionals' perceptions of the implementation of family-centered practices in child assessments. American Journal of Speech-Language Pathology, 15, 365-377.

Croteau, D. R., Hoynes, W. D., \& Milan, S. (2012). Media/society: industries, images, and audiences. Thousand Oaks, CA: SAGE Publications.

Gillett, J. N., \& LeBlanc, L. A. (2007). Parent-implemented natural language paradigm to increase language and play in children with autism. Research in Autism Spectrum Disorders, 1, 247-255.

Goldsmith, T. R., \& LeBlanc, L. A. (2004). Use of Technology in Interventions for Children with Autism. Journal of Early and Intensive Behavior Intervention, 1, 166-178.

Ha, S. B., \& Kang, S. M. (2011). Inquiry on the socio-cultural meaning of the using form and environment of smart phone: focused on the viewpoint of media-ecology studies. Journal of the Korea Contents Association, 11, 89-99.

Hailpern, J., Karahalios, K., Halle, J., DeThorne, L., \& Coletto, M. K. (2008). Visualizations: speech, language \& autistic spectrum disorder. Proceedings of the Conference on Human Factors in Computing System, Florence, Italy, 3591-3596.

Hanna, K., \& Rodger, S. (2002). Towards family-centred practice in paediatric occupational therapy: a review of the literature on parent-therapist collaboration. Australian Occupational Therapy Journal, 49, 14-24.

Heimann, M., Nelson, K. E., Tjus, T., \& Gillberg, C. (1995). Increasing reading and communication skills in children with autism through an interactive multimedia computer program. Journal of Autism and Developmental Disorders, 25, 459-480.

Hemmeter, M. L., \& Kaiser, A. P. (1994). Enhanced milieu teaching effects of parent-implemented language intervention. Journal of Early Intervention, $18,269-289$.

Heo, M. H. (2012). SPSS Questionnaire Survey Methods: from Basics to Practical Use. Seoul: Hannarae Publishing Co.

Hong, E. S. (2013). The Relationship among problem behaviors of children with disabilities and the life-quality of their parents. Korean Journal of Special Education, 48, 365-380.

Hoque, M. E., Lane, J. K., El Kaliouby, R., Goodwin, M., \& Picard, R. W. (2009). Exploring speech therapy games with children on the autism spectrum. Proceedings of the 10th Annual Conference of the International Speech Communication Association (INTERSPEECH 2009), Brighton, UK, 1455-1458

Hwang, I., Yoo, C., Hwang, C., Yim, D., Lee, Y., Min, C., ... Song, J. (2014). TalkBetter: family-driven mobile intervention care for children with language delay. Proceedings of the 17th ACM Conference on Computer Sup- 
ported Cooperative Work \& Social Computing, Baltimore, MD, 1283-1296.

Hwang, S. H., \& Choi, S. S. (2012). Parents' perceptions on self-advocacy skills of children with and without disabilities. Korean Journal of Special Education, $47,353-374$.

Hwang, Y. L., Huang, P. W., \& Hsu, L. P. (2014). Impacts of language learning based on computer-assisted language learning instruction. Applied Mechanics and Materials, 479, 928-933.

June, K. J., \& Back, Y. S. (2004). A parental survey on public awareness programs for early identification and intervention of infants and young children with special needs. Korean Journal of Early Childhood Special Education, 4, 59-77.

Jung, P., \& Yim, D. (2011). Meta-analysis of parent training: focus on children. Korean Journal of Communication Disorders, 16, 521-539.

Kaiser, A. P., \& Roberts, M. Y. (2013). Parent-implemented enhanced milieu teaching with preschool children who have intellectual disabilities. Journal of Speech, Language, and Hearing Research, 56, 295-309.

Kim, J. H., \& Hwang, S. S. (2013). Parents' practices and demands in speech therapy service delivery by age groups. Journal of Speech \& Hearing Disorders, 22, 273-297.

Kim, J. H., \& Kim, S. Y. (2012). Media Contents 2.0: the dawning of the smart media age (IT strategy reports). Seoul: KT Economic Management Research Institute.

Korea Communications Commission. (2013). Survey of Using Smartphone in the Second Half of 2012. Seoul: Author.

Korea Information Society Development Institute. (2013). Research of policy (12-09): Assessment of competition in the communications market (2012). Seoul: Author.

Korea National Institute for Special Education. (2011). Nation-wide survey on special education. Asan, Korea: Author.

Lee, E. K., \& Seok, D. I. (2006). The contents of parent education about parent participation style for children with speech-language disorder. Journal of Speech \& Hearing Disorders, 15, 33-48.

Lee, E. K., \& Seok, D. I. (2007). The development of assessment and evaluation system to parent education program. Journal of Speech \& Hearing Disorders, 16, 149-163.

Lee, H. J., Kang, M. K., \& Kim, Y. T. (2013). Current practice and support needs in smart media perceived by the mothers of children with communication difficulties. Communication Sciences and Disorders, 18, 163-171.

Lee, Y. K., \& Lee, H. J. (2013). Conversational turn-taking of toddlers with language delay. Special Education Research, 12, 357-377.
Leijten, P., Raaijmakers, M. A., de Castro, B. O., \& Matthys, W. (2013). Does socioeconomic status matter? A meta-analysis on parent training effectiveness for disruptive child behavior. Journal of Clinical Child \& Adolescent Psychology, 42, 384-392.

Lim, J. H., \& Park, E. H. (2012). Development and research trends of application as the smart education media for ASD. Journal of the Korean Association for Persons with Autism, 12, 93-117.

McGrath, P. J., Sourander, A., Lingley-Pottie, P., Ristkari, T., Cunningham, C., Huttunen, J., ... Watters, C. (2013). Remote population-based intervention for disruptive behavior at age four: study protocol for a randomized trial of Internet-assisted parent training (Strongest Families Finland-Canada). BMC Public Health, 13, 985.

McNaughton, D., \& Light, J. (2013). The iPad and mobile technology revolution: benefits and challenges for individuals who require augmentative and alternative communication. Augmentative and Alternative Communication, 29, 107-116.

McTavish, F. M., Chih, M. Y., Shah, D., \& Gustafson, D. H. (2012). How patients recovering from alcoholism use a smartphone intervention. Journal of Dual Diagnosis, 8, 294-304.

Minchom, S., Shepherd, M., White, N., Hill, J., \& Lund, P. (2003). Service needs of hearing-impaired children and their families: report of a survey of parental attitudes. Deafness \& Education International, 5, 93-107.

Moeller, M. P. (2000). Early intervention and language development in children who are deaf and hard of hearing. Pediatrics, 106, e43-e43.

Nes, A. A., van Dulmen, S., Eide, E., Finset, A., Kristjánsdóttir, Ó. B., Steen, I. S., ... Eide, H. (2012). The development and feasibility of a web-based intervention with diaries and situational feedback via smartphone to support self-management in patients with diabetes type 2. Diabetes Research and Clinical Practice, 97, 385-393.

Pennington, L., Thomson, K., James, P., Martin, L., \& McNally, R. (2009). Effects of it takes two to talk-The Hanen program for parents of preschool children with cerebral palsy: finding from an exploratory study. Journal of Speech, Language and Hearing Research, 55, 1655-1670.

Reese, E., Sparks, A., \& Leyva, D. (2010). A review of parent interventions for preschool children's language and emergent literacy. Journal of Early Childhood Literacy, 10, 97-117.

Roberts, M. Y., \& Kaiser, A. P. (2012). Assessing the effects of a parent-implemented language intervention for children with language impairments using empirical benchmarks: a pilot study. Journal of Speech, Language, and Hearing Research, 55, 1655-1670. 
Rogers, T. R., Forehand, R., Griest, D. L., Wells, K. C., \& McMahon, R. J. (1981). Socioeconomic status: effects on parent and child behaviors and treatment outcome of parent training 1. Journal of Clinical Child \& Adolescent Psychology, 10, 98-101.

Romski, M., Sevcik, R. A., Adamson, L. B., Smith, A., Cheslock, M., \& Bakeman, R. (2011). Parent perceptions of the language development of toddlers with developmental delays before and after participation in parentcoached language interventions. American Journal of Speech-Language Pathology, 20, 111-118.

Rosenbaum, P., King, S., Law, M., King, G., \& Evans, J. (1998). Family-centred service: a conceptual framework and research review. Physical \& Occupational Therapy in Pediatrics, 18, 1-20.

Sim, H. S., Kim, Y. T., Kim, J. S., Kim, H. H., Bae, S. Y., Shin, M. J., ... Kwon, M. S. (2011). Introduction to communicative disorders. Seoul: Hakjisa.

Suskind, D., Leffel, K. R., Hernandez, M. W., Sapolich, S. G., Suskind, E., Kirkham, E., ... Meehan, P. (2013). An exploratory study of "Quantitative Linguistic Feedback" effect of LENA feedback on adult language production. Communication Disorders Quarterly, 34, 199-209.

Sutherland, D., van der Meer, L., Sigafoos, J., Mirfin-Veitch, B., Milner, P., O’Reilly, M. F., ... Marschik, P. B. (2014). Survey of AAC Needs for adults with intel- lectual disability in New Zealand. Journal of Developmental and Physical Disabilities, 26, 115-122.

Thiemann-Bourque, K. S., Warren, S. F., Brady, N., Gilkerson, J., \& Richards, J. A. (2014). Vocal interaction between children with Down syndrome and their parents. American Journal of Speech-Language Pathology, 23, 474-485.

Ward, S. (1999). An investigation into the effectiveness of an early intervention method for delayed language development in young children. International Journal of Language \& Communication Disorders, 34, 243-264.

Warren, Z., Stone, W., \& Humberd, Q. (2009). A training model for the diagnosis of autism in community pediatric practice. Journal of Developmental \& Behavioral Pediatrics, 30, 442-446.

Wood, W. D., \& Baker, J. A. (1999). Preferences for parent education programs among low socioeconomic status, culturally diverse parents. Psychology in the Schools, 36, 239-247.

Yoo, K. H. (2007). A correlational study on uncertainty, mastery and appraisal of uncertainty in hospitalized children's mothers. Journal of Korean Academy of Nursing, 37, 594-602.

Zimmerman, F. J., Gilkerson, J., Richards, J. A., Christakis, D. A., Xu, D., Gray, S., ... Yapanel, U. (2009). Teaching by listening: the importance of adult-child conversations to language development. Pediatrics, 124, 342-349. 
Appendix. 설문지(공통 문항)

\section{II . 의사소통기능 증진을 위한 스마트폰 어플리케이션 콘텐츠 요구도}

1. 아동의 의사소통기능 증진을 위한 스마트폰 어플리케이션을 사용해 보신 적이 있습니까?

(1) 있다 (2) 없다

2-1. 있다면, 어떤 어플리케이션입니까? (복수 선택 가능)

(1) 아동용 멀티미디어(동영상, 동화·동요, 게임 등)

(2) 부모 교육(아동의 발달 연령에 맞는 강의 동영상 및 사례에 대한 자료, 아동과의 의사소통 시 올바른 대응 방법과 부모의 역할에 대한 조언 및 피드백 등 제공)

(3) 의사소통 보조 수단(그림 및 글자판 또는 말소리 출력기 등을 통하여 아동의 의사소통 의도를 대신해주거나 돕는 어플리케이션 등)

(4) 기타:

4. 아동과의 의사소통기능 증진을 위한 스마트폰 어플리케이션 콘텐츠가 개발된다면, 그 필요성에 대해 어떻게 생각하십니까? 아래에 제시된 콘텐츠의 종류에 따른 필요 정도를 기입해 주십시오

\section{콘텐츠의 종류}

\begin{tabular}{ccccc}
\multicolumn{5}{c}{ 평가 척도 } \\
\hline 전혀 & 필요 & 보통 & 필요 & 매우 \\
필요없다 & 없다 & 이다 & 하다 & 필요하다 \\
\hline
\end{tabular}

1. 의사소통 상황에서 아동의 발화에 대한 양적인 정보(발화의 양, 발화 유지 시간 등)를 제공하는 콘텐츠

2. 의사소통 상황에서 아동의 대화 상대자(부모 등)의 발화에 대한 양적인 정보(발화의 양, 발화 유지 시간 등) 를 제공하는 콘텐츠

3. 의사소통 상황에서 아동의 대화 상대자(부모 등)의 발화 속도에 대한 정보를 제공하는 콘텐츠

4. 의사소통 상황에서 아동이 먼저 대화를 시작하는 횟수에 대한 정보를 제공하는 콘텐츠

5. 의사소통 상황에서 아동이 성인의 발화에 구어로 반응하는 횟수에 대한 정보를 제공하는 콘텐츠

6. 의사소통 상황에서 아동과 성인의 대화 차례 주고받기 횟수에 대한 정보를 제공하는 콘텐츠

7. 의사소통 상황에서 참여자 간 상호작용의 원활성에 대한 정보(침묵 유지 시간, 각 참여자의 발화 비율 등) 를 제공하는 콘텐츠

8. 의사소통 상황에서 아동의 대화 상대자(부모 등)에게 실시간 피드백을 제공하는 콘텐츠

9. 아동의 의사소통기능 증진과 관련된 이론 및 기술을 참고할 수 있는 문서 형태로 제공하는 콘텐츠

10. 아동의 의사소통기능 증진과 관련된 이론 및 기술을 전문가가 동영상을 통해 강의하는 콘텐츠

11. 아동의 의사소통기능 증진과 관련된 기술을 전문가가 시범을 보임으로써 동영상을 통해 제공하는 콘텐츠 


\section{국문초록}

\section{스마트폰 프로그램 개발을 위한 의사소통장애 아동 부모 및 전문가 요구 분석 \\ 임동선 · 김신영 · 박원정 · 천성혜 · 이여진 \\ 이화여자대학교 언어병리학과}

배경 및 목적: 본 연구는 의사소통장애 아동의 부모 및 전문가(언어치료사)를 대상으로 ‘모바일 기반 의사소통 능력 증진 콘텐츠’의 요 구도 및 필요성을 조사하여 언어중재 도구로서 스마트폰의 가능성을 탐색하고자 한다. 방법: 선행연구 및 기존의 검사도구, 통계청 자 료를 참고하여 설문문항을 개발하고, 전문가 2인에게 문항의 타당도와 적절성을 검증받은 후 사전검사를 통하여 설문문항을 완성하 였다. 대면 및 우편 발송, 온라인 참여를 통하여 설문조사를 실시하였으며, 총 189부(부모용 96부, 전문가용 93부)의 설문지가 분석 대 상이 되었다. 결과: 의사소통장애 아동의 부모 96 명과 언어치료사 93 명, 총 189 명의 연구 대상자 중 과반수가 아동의 의사소통능력 증 진을 위한 스마트폰 어플리케이션 사용 경험이 있는 것으로 나타났다. 두 집단 모두 부모교육과 관련된 콘텐츠 요구도가 높았으며, 아동 과의 대화 상황에서 발화의 양적인 정보에 대한 요구도는 자녀가 가진 의사소통 어려움의 종류와 무관하게 부모 집단에서 유의하게 높 은 것으로 나타났다. 요구도가 높게 나타난 부모교육의 경우, 부모는 그 필요성을 높게 평가하였으나, 현재 이루어지고 있는 치료기관과 부모 간 협력은 주로 부모상담의 형식인 것으로 조사되었다. 논의 및 결론: 본 연구결과를 바탕으로 부모와 언어치료사의 실제적 요구 를 반영한 스마트폰 어플리케이션을 개발하여 일상생활에서 사용할 수 있는 의사소통장애 선별 및 치료 도구로서의 가능성을 모색하 는 후속 연구가 필요할 것으로 보인다.

핵심어: 의사소통장애 아동, 전문가, 부모, 스마트폰, 설문조사, 요구 조사

본 연구는 2013년도 정부(미래창조과학부)의 재원으로 한국연구재단의 지원을 받아 연구되었음(NRF-2013R1A2A2A03068010).

\section{참고문헌}

국립특수교육원(2011). 특수교육실태조사: 아산: 국립특수교육원.

김정훈, 김승윤(2012). 영상 컨텐츠 2.0: 스마트 미디어 시대의 도래(IT 전략 보고서). 서울: KT경제연구소.

김지현, 황상심(2013). 자녀 연령에 따른 장애아 부모의 언어치료 실태 및 요구조사. 언어치료연구, 22, 273-297.

방송통신위원회(2013). 2012년 하반기 스마트폰 이용실태조사. 서울: 방송통신위원회.

심현섭, 김영태, 김진숙, 김향희, 배소영, 신문자, 이승환, 이정학, 한재순, 윤혜련, 김정미, 권미선 (2011). 의사소통장애의 이해. 서울: 학지사.

유경희(2007). 입원 아동 어머니가 지각하는 불확실성, 극복력 및 불확실성 인지의 관계. 대한간호학회지, 37, 594-602.

이윤경, 이효주(2013). 표현언어발달지체 영유아의 대화차례 주고받기 특성. 특수교육, 12, 357-377.

이은경, 석동일(2007). 장애아동 부모교육 프로그램의 평가모형 개발. 언어치료연구, 16, 149-163.

이은경, 석동일(2006). 부모참여 유형별 언어장애아동 부모교육 내용고찰. 언어치료연구, 15, 33-48.

이현정, 강민경, 김영태(2013). 어머니가 인식한 자녀의 의사소통 어려움과 스마트미디어 활용 현황 및 요구조사. 언어청각장애연구, 18, 163-171.

임장현, 박은혜(2012). ASD인을 위한 스마트 교육 미디어로서의 앱 개발 및 연구현황 분석. 자폐성장애연구, 12, 93-117.

전경자, 백유순(2004). 부모의 장애아동 조기발견 및 중재에 관한 정보습득 실태. 유아특수교육연구, 4, 59-77.

정보통신정책연구원(2013). 정책연구(12-09) 통신시장 경장생황 평가 (2012년도). 서울: 정보통신정책연구원.

정필연, 임동선(2011). 메타분석을 통한 부모교육프로그램의 효과 연구. 언어청각장애연구, 16, 521-539.

조용상(2011). 스마트 미디어가 보여주는 IT 서비스의 미래. SMART on ICT 2011 컨퍼런스 발표 자료집. 서울: 한국교육학술정보원.

하성보, 강승묵(2011). 스마트폰의 이용형태와 이용환경이 갖는 사회문화적 함의 고찰: 미디어생태학적 관점을 중심으로. 한국콘텐츠학회논문지,

$11,89-99$.

허명회(2012). SPSS 설문지 조사방법: 기본과 활용. 서울: 한나래출판사

홍은숙(2013). 장애자녀의 문제행동과 부모의 삶의 질 간의 관계. 특수교육학연구, 48, 365-380.

황선하, 최승숙(2012). 자녀의 자기옹호기술에 대한 장애학생 부모와 일반학생 부모의 인식 비교. 특수교육학연구, 47, 353-374. 